\title{
The Effects of Manpower Planning and Crises Management in Public Sector: A Case Study of Nigerian Institute for Oil Palm Research in Edo State
}

\author{
Emily Akintoye ${ }^{1}$ and Sunday Okungbowa Uhunmwuangho ${ }^{2}$ \\ 1.Department of Sociology and Anthropology, Benson Idahosa University \\ 2.Department of Political Science \& Public Administration, Benson Idahosa University, \\ Benin City, Nigeria \\ *Email: uhunmwuangho4you@yahoo.com
}

\begin{abstract}
This paper examines the Effects of Manpower Planning and Crises Management in Public Sector: A Case Study of Nigerian Institute for Oil Palm Research (NIFOR) in Nigeria as a democratic sustainability. It evaluates how effective the organization policy have been able to restructure the political economy of Nigeria by training of its manpower and being able to resolve crises in the system. Since the early 1990s, the issue of Good Governance has become an important concept in the International Development debates and Policy discourse. Over the last decade however, Public Sector, especially Nigerian NIFOR has not adequate avail their workers opportunity to attend short-term courses if they cannot be released for training courses of between 1 to 3 years. This has led to several crises in the organization which would have been avoided, if adequate crises management techniques were put in place. The Nigerian Institute for Oil Palm Research (NIFOR) has not also imbibe the policy of inclusiveness. In the course of this study, the Effects of Manpower Planning and Crises Management in Public Sector: A Case Study of Nigerian Institute for Oil Palm Research (NIFOR), Edo State were brought to the fore while the objectives of the study are well spelt out. Hypotheses were postulated and the Scientific Management Theory was used to explicate the works. Data were obtained from both primary and secondary sources. From the primary sources, the survey method, that is, the use of questionnaire designed and adopted. Data obtained from this method were analyzed with the aid of Simple Percentage. Thereafter, the five researchable hypotheses were tested and accepted while the null hypotheses were rejected. The implication is that there was relationship between the dependent and independent variables. Generally, the paper brought to focus that the Effects of Manpower Planning and Crises Management is a collective effort in reaching a compromise in the management of Public Sector in Nigeria and it has contributed immensely to the growth and development of public enterprise elsewhere. Finally, it suggests policy and crises management techniques and recommendation which are aimed at repositioning Public Sector like NIFOR not only in Edo State in particular, but also in Nigeria in general.
\end{abstract}

Keywords: Crises, Management, Resolution, Effects, Public, Manpower

DOI: $10.7176 / \mathrm{DCS} / 12-2-03$

Publication date: February $28^{\text {th }} 2022$

\section{Introduction}

The management of human resources occupies a fundamental position in any Public Establishment. If organization objectives and excellence must be achieved, the crucial role and importance of the people that constitute the organization must be given a pride of place. It is this recognition that has attracted the attention of several scholars to the field of Human Resources Development (Okoh, 2015).

Manpower Planning and Crises Management cannot be underated in any Public Sector. Training and development are interrelated process whose importance cannot be over emphasized in any strategic human resource management and employees productivity in any public sector. Manpower development has been described as the systematic process which an organization has to go through to ensure that it has effective work force it requires to meet its present and future needs (Ibekwe, 2010:72). As jobs are becoming more and more complex, it has become imperative for employers of labour to train their workers unlike when jobs were simple and little technical knowledge was required from the workers. However, most organizations especially the public sector organizations do not consider the necessity for a well-planned and sustained training and development for members of staff in order to upgrade their performance or they are not able to cope financially with training and development programmes. As a result of this lackadaisical attitude of management towards training and manpower development, there has been a progressive decline in the ability of manpower to cope with the challenges that attend the ever unfolding new dispensation in the public sector.

The human resource (Manpower Planning) is considered the most critical to any organization's survival as it ensures that adequate supply of material and financial resources are utilized to bring about the desired goals. Manpower training and development strictly defined, is the activity of management which is aimed at coordinating the requirement for and availability of different types of employees. Usually, this involves ensuring 
that the firm or organization has enough of the right kind of labour at such times as it is needed. It may also involve adjusting the requirements to the availability of supply (Okoh, 2015: 22).

It is therefore, the responsibility of every organization to help in training and developing the manpower with requisite potential to contribute their full measure, not only to the management of the enterprises, but also to the achievement of the enterprise goals and objectives. Human resources are unique in their potential to grow and develop to meet new challenges. Many individuals look at the chance to develop and move up as important in where they will seek employment. In order to facilitate employee progression, many organizations choose to spend substantial sum to train and develop their employees (Diejemoah, 2011:119).

Employee training and development is either by formal or informal procedures. Formal training is often associated with the introduction to a new job; it is also a means of keeping up with technology or procedural changes, formal training can be co-ordinated and taught by human resources or technical professional in the organization, or employees may be sent for training programmes offered by professional associations or Universities. Informal training occurs on the job and is administered by superiors and peers (Diejemoah, 2011:121).

In any public sector people's efforts or behaviour are co-ordinated in order to attain the set objectives of the organization.

Therefore, peace in Nigeria and other countries could be likened to the Biblical Aaron and Moses, who were endowed with the responsibility to bring Africa out from the bondage of despair, decline and underdevelopment. As regional powers, history has imposed on them the enormous task of finding solutions to some of the most pressing African concerns.

Conflicts or crises is inevitable among humans. When two or more social entities (i.e. individuals, groups, organizations and nations) come in contact with one another in attaining their objectives, their relationships may become incompatible or inconsistent. Relationships among such entities may become inconsistent when two or more of them desire a similar resource that is in short supply; when they have partially exclusive behavioural preferences regarding their joint action; or when they have different attitudes, values, beliefs and skills. Conflict in some form and degree is part and parcel of virtually every facet of human life (Iyamu and Salami, 2011). Some people tend to view conflict as undesirable component of human life while others through history and experience came to the conclusion that conflict can indeed lead to changes regarded as desirable in terms of generally acceptable human values. As a matter of fact, conflict exists in every organization of human assembly and cannot be avoided. Conflict is ubiquitous at all levels of human social relationships. No wonder (Uhunmwuangho and Epelle, 2011) posits that conflicts/crises performs many positive functions (such as enhancing social solidarity, classifying values, stimulating growth and promoting learning). They went further to say that the common phrase that states "without peace which negative conflict offers there cannot be meaningful development" is incontrovertible. Conflict is not deviant or sick behaviour. Industrial conflicts represent the basic expression of the inability of the parties involved to mutually or reciprocally satisfy each other's needs (Akintoye, 2014). According to Dimeji Bankole, former Speaker of the Nigeria House of Representative, the presence of military force in Niger Delta then was a solution and to enforce peace in the region.

Conflict is further defined as a struggle over values or claims to status, power and scare resources among two or more parties that perceive incompatible interests or express hostile attitudes. Accordingly, it can also be seen as a struggle or contest between people with opposing needs, ideas, beliefs, values or goals. Conflict is not necessarily war but there is hardly any war without declared or undeclared conflict. There are two sides to conflict. Conflict could degenerate to non-productive results in the form of irreparable damages. It could also culminate in some beneficial outcome in the form of equity or emergence of a new situation agreeable to the parties hitherto in conflict. The determining factor therefore is how a conflict is managed (Odigie, 2012).

Crises/conflicts management is viewed as a wide term that includes conflict resolution, changing the character of conflict to be positive, and encouraging peaceful cohabitation (Uhunmwuangho and Epelle, 2011) It is a long-term agreement including official organizations and institutions for stopping and averting conflict anytime it is ready to erupt. In other words, conflict management is a name for the various methods in which individuals address complaints, crises management, defending what they believe to be right against what they believe to be wrong. Conflict resolution necessitates a mix of intellectual and interpersonal abilities. It has an impact on individual happiness, group performance, and organizational effectiveness (Uhunmwuangho and Epelle, 2011).

The Effects of Manpower Planning and Crises Management in Public Sector: A Case Study of NIFOR, despite its wide acceptance and usage, have exhibited some difficulties in the course of its operations.

\section{Problem}

Because the interests of many stakeholders, such as managers and employees, are sometimes conflicting, conflicts/crises are unavoidable aspect of company's life (Jones, Gorge, and Hill, 2010). As long as individuals 
fight for employment, resources, power, recognition, and security, there will be conflict in any organization. This leads to a situation in which they annoy one other in order to attain their goals. Because of the shortage of freedom, position, and resources, conflict develops in communities. People who value independence are less likely to favour interconnectedness and, to some extent, group compliance. As a result, those seeking power compete with others for position or prestige within the group.

Even though there exist in Nigeria, frightening and draconian statutory provisions against strike action, the problem remains that there are areas of conflicts/crises in the said statutory provisions which could operate to render nugatory the statutes on this score. Section 13 of the then Trade Disputes Decree of 1976, which became section 17 and has since become section 18 of the extant Trade Dispute Act as identified, proves elaborately for a non-strike situation before the issue of an award of the National Industrial Court which was created by the said Act (Ikelegbe, 2009).

It is doubtless that Nigeria is strike-prone. Since the attainment of independence, Nigeria has had to grapple with military labour laws in the relationship of workers and employers. According to Idubor, on record is the fact that, since 1960 when Nigeria attained independence, the National Assembly enacted one labour statute in the First Republic. In 1962, the then Governor General of Nigeria, Dr. Nnamdi Azikiwe signed into law, a statute on the National Provident Fund. In May 1981, the National Assembly in the Second Republic enacted the Nigerian Labour Congress inspired National Minimum Wage Act, which President Shehu Shagari signed into Law on $11^{\text {th }}$ May, 1981. In 2006, the current National Assembly enacted the National Industrial Court Act. This is without prejudice to the National Minimum Wage (Amendment Act of 2001 and the Trade Unions Amendment Act of 2005), that were merely an amendment to the principal statutes in both cases. The point being made here is that it is only the military regime of the various maximum rulers in Nigeria that produced almost all the labour legislation in place in Nigeria today. Ironically, the extant constitution retains these draconian laws, and government as a sovereign found it painless to continue to rely on those statutes with no effort at all at bringing public Bills to the National Assembly to amend them in conformity with the constitution (Idubor, 2010).

For most Nigerians however, the pressing problems of everyday survival remain the highest immediate priority. The functional pressure groups faced a number of problems, as a result of their belief in and in the process of pursing democratic ideals. One of such obstacles was the interference of government in the affairs of these groups. This has contributed tremendously towards weakening the groups. Besides, this meddlesomeness in the groups' activities has created specific problems for the different groups in the society. For instance, it led to the emergence of Pascal Bafyau, a military apologist as the leader of Nigerian Labour Congress (NLC). It also resulted in the inability of Nigerian Bar Association (NBA) to constitute its central leadership from 1992 to 1995, while the Nigerian Medical Association (NMA) was almost polarized into groups or camps on different occasions.

In some extreme cases, the government has wielded the big stick by outright proscription of some of these groups. The purpose was to keep them out of circulation for as long as possible so that they would not pose any threat to undemocratic government. It was in an effort to achieve this aim that the NLC, ASUU and NANS were proscribed at different times (Abimbola, 2013). Similarly, unfavourable legislations or policies were imposed on these groups to incapacitate them and in the process render them useless or at best ineffective. Such unfavourable legislations or policies are many among which are the National Economic Emergency Power Decree 22 of 1985, the Trade Union (Miscellaneous Provisions) Decree 17 of 1986, Decrees 12 and 16 of 1986 as well as Decree 47 of 1987 among others. Through this policy/process, ASUU was disaffiliated from the NLC (through the provision of Decree 17 of 1986) because of what government considered as "radical influence" on the NLC (CDHR, 2009).

Consequently the emerging issues include:

i) What are the constraint militating against the Manpower Planning and Crises Management in NIFOR?

ii) What are the problems associated with the effective Manpower Planning and Crises Management in NIFOR?

iii) To what extent does the Public Sector Management address Union Crises in NIFOR?

\section{Objectives}

The specific objectives are:

(a) What are the constraint militating against the Manpower Planning and Crises Management in NIFOR?

(b) What are the problems associated with the effective Manpower Planning and Crises Management in NIFOR?

(c) To what extent does the Public Sector Management address Union Crises in NIFOR? 


\section{Hypotheses}

In order to achieve these objectives, the following research hypotheses were formulated:

1. There is no significant relationship between constraint militating against Manpower Planning and Crises Management in NIFOR.

2. There is no significant relationship between Effective Manpower Planning and Crises Management in NIFOR

3. There is no significant relationship between Public Sector and Management to address Crises in NIFOR.

\section{Theoretical Exposition}

The theory considered as relevant to this discourse is Frederick W. Taylor's "Scientific Management Theory" proposed in 1911. The Scientific Management School comprises those who first applied scientific principles to management with a view to adding increased productivity and efficiency in the workplace. Their work formed the basis of further development of other management thoughts.

The scientific management theory called for optimizing the way that task were performed and simplifying the jobs enough so that workers could be trained to perform their specialized sequence of motion in the one "best" way. In the Steel Industry, Taylor observed the phenomenon of workers working below their capacity, that is, soldering. This he attributed to three causes (Okoh, 2015:101):

- $\quad$ workers belief that if they become more productive, fewer of them would be needed.

- $\quad$ non - incentive wage system discourage productivity.

- $\quad$ workers waste much of their efforts by relying on rule- of - thumb method (old system) rather than optimal methods that can be determined by scientific study of the task.

To counter 'soldering' and improve efficiency, Taylor began to conduct experiments to determine the best level of performance for certain jobs and what was necessary to achieve this performance. As a result, he proposed four principles of scientific management;

- that all Managers must be trained to use scientific principles in replacing the old rule- of- thumb method for solving problems

- that managers should select and train workers rather than let them choose their work habit and procedures.

- $\quad$ that managers should divide the work as much as possible between themselves and workers.

- that Managers should cooperate and motivate the workers to ensure that all work is done in accordance with the scientific management.

In the public sector system (NIFOR), 'soldering' (low productivity) is quite obvious. The scientific management theory therefore forms a good guide for this study since it emphasized the training and development of human resources for higher productivity and attainment of organizational objectives

In a nutshell, this framework is associated with this paper because of the characteristic nature of the Scientific Management Theory that make up the polity under study.

\section{Methodology}

This paper adopted a descriptive survey method. The research is centered on Effects of Manpower Planning and Crises Management in the Public Sector system, A Case Study of Nigerian Institute for Oil Palm Research (NIFOR) in Edo State, Benin City. The period (time) for this investigation is 2009 to 2020 The population of the study consist of 250 base on two categories (Senior and Junior) staff of the various departments in NIFOR sampled (see table one). Out of this number, one hundred and seventy of them met our criteria and therefore form our sample size as can be seen in table one below: 
TABLE 1: POPULATION OF STUDY

\begin{tabular}{|c|c|c|c|c|c|}
\hline $\mathrm{S} / \mathrm{No}$ & Sampled Departments & $\begin{array}{l}\text { Category of } \\
\text { Respondents }\end{array}$ & $\begin{array}{l}\text { No. of } \\
\text { Returned } \\
\text { Questionnaires }\end{array}$ & $\begin{array}{l}\text { No. of Not } \\
\text { Returned/Invalid } \\
\text { Questionnaires }\end{array}$ & $\begin{array}{l}\text { Total No. of } \\
\text { Sampled } \\
\text { Respondents }\end{array}$ \\
\hline \multirow[t]{2}{*}{1.} & \multirow{2}{*}{ Seed Production } & Senior Staff & 16 & 6 & \multirow[b]{2}{*}{31} \\
\hline & & Junior Staff & 5 & 4 & \\
\hline \multirow[t]{2}{*}{2.} & \multirow[t]{2}{*}{ Oil Mill. } & Senior Staff & 17 & 8 & \multirow[b]{2}{*}{31} \\
\hline & & Junior Staff & 4 & 2 & \\
\hline \multirow[t]{2}{*}{3.} & \multirow[t]{2}{*}{ Entomology } & Senior Staff & 18 & 7 & \multirow[b]{2}{*}{32} \\
\hline & & Junior Staff & 4 & 3 & \\
\hline \multirow[t]{2}{*}{4.} & \multirow{2}{*}{$\begin{array}{l}\text { Agricultural } \\
\text { Economics }\end{array}$} & Senior Staff & 15 & 7 & \multirow[b]{2}{*}{31} \\
\hline & & Junior Staff & 6 & 3 & \\
\hline \multirow[t]{2}{*}{5.} & \multirow[t]{2}{*}{ Plant Pathology } & Senior Staff & 17 & 6 & \multirow[b]{2}{*}{32} \\
\hline & & Junior Staff & 5 & 4 & \\
\hline \multirow[t]{2}{*}{6.} & \multirow[t]{2}{*}{ Agronomy } & Senior Staff & 17 & 8 & \multirow[b]{2}{*}{31} \\
\hline & & Junior Staff & 4 & 2 & \\
\hline \multirow[t]{2}{*}{7.} & \multirow[t]{2}{*}{ Audit } & Senior Staff & 18 & 7 & \multirow[b]{2}{*}{31} \\
\hline & & Junior Staff & 4 & 3 & \\
\hline \multirow[t]{2}{*}{8.} & \multirow[t]{2}{*}{ Biochemistry } & Senior Staff & 16 & 6 & \multirow[b]{2}{*}{31} \\
\hline & & Junior Staff & 5 & 4 & \\
\hline TOTAL & & & 170 & 80 & 250 \\
\hline
\end{tabular}

Source: Field Survey, 2021.

Both primary and secondary sources of data were explored in trying to generate data for this study. The specific information required for the study was The Effects of Manpower Planning and Crises Management in Public Sector: A Case Study of Nigerian Institute for Oil Palm Research (NIFOR) in Edo State. The questionnaire formed the main instrument used in generating primary data while documented information on prints that were relevant to this study constituted the secondary source of generating data. To complement the information received through the questionnaire, respondents were also interviewed. As the research was based on attitude and opinions, the statistical tools employed in analyzing responses included tables and simple percentages. All the one hundred and seventy copies of the questionnaire distributed to the respondents studied were duly completed and returned in a useable form. The Statistical Package for Social Sciences (SPSS) was used for the data analysis.

\section{Demographic Data}

Out of all the one hundred and seventy respondents, eighty (47\%) of them were married; fifty (29\%) were single while twenty one $(13 \%)$ were divorced. The remaining nineteen $(11 \%)$ were either widows or widowers. Thirty $(18 \%)$ of them were within the age bracket of $18-25$, Fifty $(29 \%)$ were between the age bracket of 26-35 years, while eighty $(47 \%)$ were within the age bracket of 36-45 years. The remaining forty six years and above were ten $(6 \%)$.

\section{TABLE 2: Hypothesis 1}

There is no significant relationship between constraint militating against Manpower Planning and Crises Management in NIFOR.

\begin{tabular}{|l|c|c|}
\hline Responses & No. of Respondents & Percentage \\
\hline Yes & 110 & 65 \\
\hline No & 60 & 35 \\
\hline Total & 170 & 100 \\
\hline
\end{tabular}

\section{Source: Statistical Analysis}

Table 2 showed that $110(65 \%)$ of the total respondents agreed that there was is constraint militating against Manpower Planning and Crises Management in NIFOR. Thereby impacted negatively on people enjoying the dividends of democracy in the establishment in Edo State in particular and Nigeria in general.

Therefore, hypothesis one which states that there is no significant relationship between constraint militating against Manpower Planning and Crises Management in NIFOR in Nigeria is accepted. 
TABLE 3: Hypothesis 2

There is no significant relationship between Effective Manpower Planning and Crises Management in NIFOR.

\begin{tabular}{|l|c|c|}
\hline Responses & No. of Respondents & Percentage \\
\hline Yes & 105 & 62 \\
\hline No & 65 & 38 \\
\hline Total & 170 & 100 \\
\hline
\end{tabular}

\section{Source: Statistical Analysis}

Table 3 showed that $105(62 \%)$ of the respondents agreed that there was correlation between Effective Manpower Planning and Crises Management in NIFOR and also Labour Congress to free itself for greater administrative responsibility while $65(38 \%)$ were not satisfied or disagreed.

TABLE 4: Hypothesis 3

There is no significant relationship between Public Sector and Management to address Crises in NIFOR.

\begin{tabular}{|l|c|c|}
\hline \multicolumn{1}{|c|}{ Responses } & No. of Respondents & Percentage \\
\hline Yes & 120 & 71 \\
\hline No & 50 & 29 \\
\hline Total & 170 & 100 \\
\hline
\end{tabular}

Source: Statistical Analysis

Table 4 showed that $120(71 \%)$ of the respondents agreed that the Public Sector that is NIFOR is not equipped with rudiments tat address crises in the establishment and which has largely affected the performance of Management to expectation of employees sampled which led to low output while 50 (29\%) disagreed with the opinion.

Therefore, the hypothesis which states that there is no significant between Public Sector and Management to address Crises in NIFOR in the establishment was accepted.

\section{Findings Based On Hypotheses}

Based on the analysis of the hypotheses, all the research hypotheses were positive which implies that $\left(\mathbf{H}_{\mathbf{r}}\right) \mathbf{1 - 3}$ were accepted.

More so, the study revealed that the Effects of Manpower Planning and Crises Management in Public Sector: A Case Study of Nigerian Institute for Oil Palm Research (NIFOR) and Labour Conflict is not labour friendly and which have more relevance and impacted negatively on the non-inclusiveness in decision making and which affect staff enjoying the dividends of democracy in Nigerian Democratic system.

1. Furthermore, this paper have highlighted several challenges and solutions as per the findings in the hypothesis carried out in the research. However, again, it was found that the pattern of relationship between workers and bosses in decision making in NIFOR establishment have slow down developmental stride which led to masses suffering in midst of plenty.

2. It was revealed that developments in recent times have whittled down.

Several establishments normally focus attention on the other means of resolving conflicts and/or crises in their activities and functions. The sample organizations in Nigeria in general and Edo State in particular are no exceptions. To do otherwise may be to lose its identity and resource base.

3. It was also revealed in the findings that the major view held by the working class in the sample organizations is that some Public Sectors will destroy the industrial relations system and should be resisted if possible amended to suit the interest of workers of the establishment is not put in place.

4. Finally, the study also revealed that federalism in Nigeria has failed

to unite the country, because rapid and even development across the length and breadth of the country has failed to checkmate the many recent expressions of ethnic, religious and cultural bigotry that has led to deaths of many innocent and unarmed Nigerians, young and old. See below the political map of Nigeria.

See figure 1 below for more details of Nigeria Political map. 


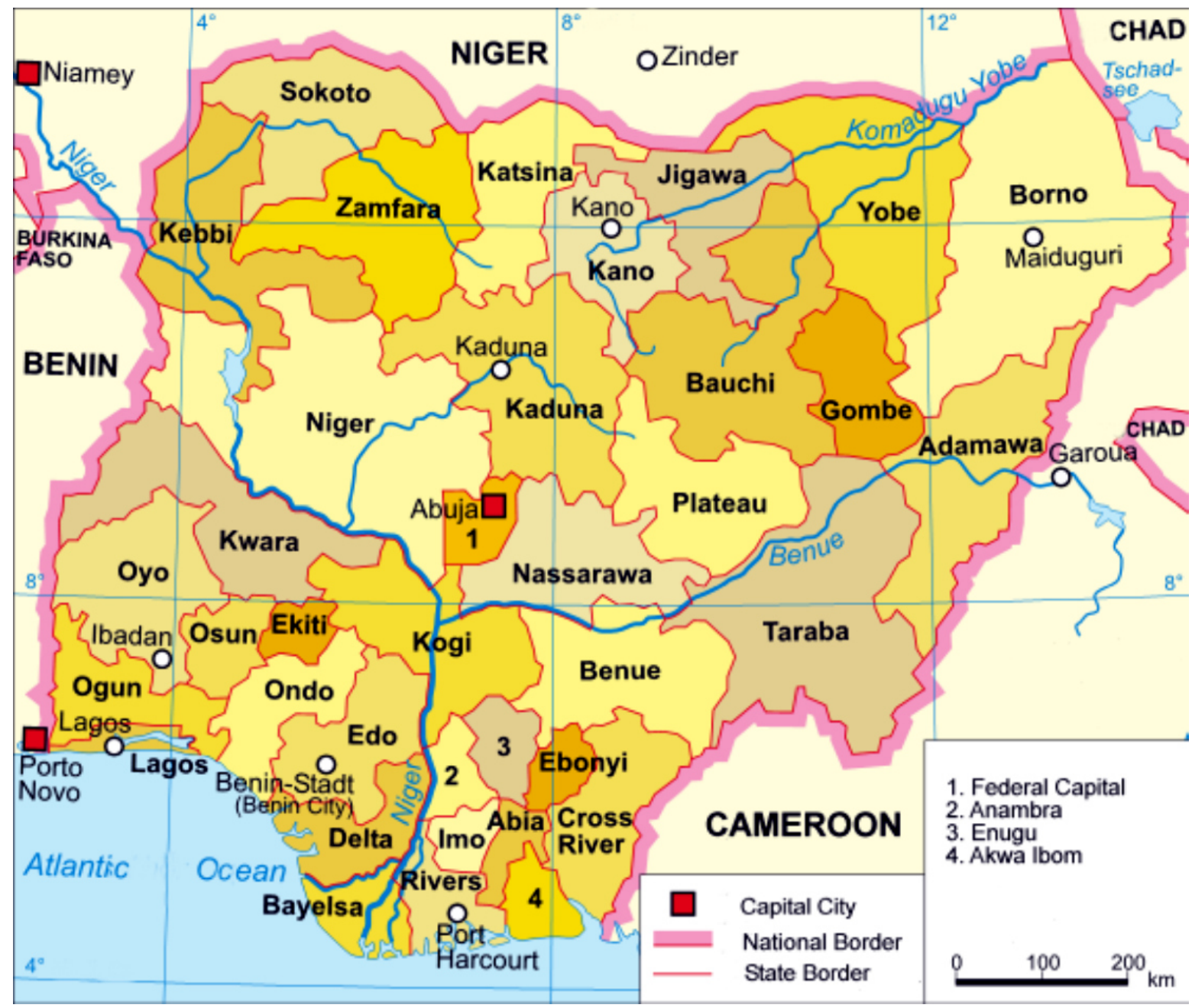

Figure 1: Political map of Nigeria. Source: Wilkipedia catched 20 November, 2021

\section{Conclusion And Recommendations}

For the high point of this study, data covering the period 2009 to 2020 were collected from the survey which was based on Nigerian Institute for Oil Palm Research (NIFOR) in Edo State, Nigeria. The Departments Seed Production, Oil Mill, Entomology, Agricultural Economics, Plant Pathology, Agronomy, Audit and Biochemistry.

Data obtained from this method were analyzed with the aid of Simple Percentage. Thereafter, the three researchable hypotheses were tested and accepted while the null hypotheses were rejected. The implication is that there was relationship between the dependent and independent variables. Generally, the paper brought to focus that the Public Sector in Nigeria is a collective effort in reaching a compromise in the management of Manpower Planning and Crises Management in Nigeria and it has contributed immensely to the growth and development of several organizations elsewhere but Nigeria experience is difference.

\section{Recommendations}

Having come this far it is only fair to recommend as follows:

1. There is need to ensure that unions are properly organized in every establish and/or Public Sector like that of NIFOR so that it can tackle headlong the challenges inherent in ensuring that the welfare of workers are adequately pursued. There are many dimensions to this issue. Ethno-religious conflicts/crises in Nigeria have continued because Nigerian elites are corrupt and split along lines of religion and ethnicity. This has resulted in ethnic rivalry, suspicion and hostility among leaders. Without a bold and articulate leadership, conflicts/crises in management or prevention will always be a mirage (Longe, 2015).

2. Secondly, it is important for union leaders and those connected with the management of conflicts to be grounded in negotiation. This can be achieved through attendants at seminars, workshops and conferences. The significance of Conflict Management in Public Administration in Africa is underlined 
by the continent's underdevelopment and weaken economic growth. This points to the need for a change in the continent's approach to conflicts/crises management. Peace in Africa is not the absence of war, but the provision of the people's basic human needs.

.3. It is important to emphasize that there should be transparency in the Management of Public Sector affairs. If weak leaders are allowed to lead Public Sectors like that of NIFOR, they are not likely to achieve much and if such leaders are not transparent, they will be weak financially. This will place them at a strong disadvantage each time they have cause to negotiate with management (Akintoye and Uhunmwuangho, 2017).

4. Finally, peace would help both organs of Government solidify their leadership positions in the African Union and the New African Partnership for Development (NEPAD).

\section{References}

Abimbola A. (2013) Pressure Groups and Democratic Process, Lagos, Nordic Journal of African Studies Vol. 12 No. 1

Akintoye E. O. (2014) Trade Unions and Decision Making in Organization being unpublished Ph.D Dissertation of the Department of Sociology and Anthropology, Faculty of Social Sciences, University of Benin, Benin City, Nigeria.

Akintoye E.O. and Uhunmwuangho, S.O. (2017) - Conflict Management and Solution In Third World Countries, Port-Harcourt Journal of History and Diplomatic Studies Vol. 4 No. 2 (pp.1-25)

Committee For The Defense of Human Rights (2009) Freedom Watch, Why ASUU is on Strike, Lagos: CDHR. Diajemoah, V.P (2011) Manpower in Nigeria, Ibadan: University Press.

Enekhaze J.O. (2021) The Effect of Manpower Training and Development in Public Sector Being a

Postgraduate Seminar Paper at Department of Political Science \& Public Administration, Benson Idahosa University, Benin City, Nigeria

Longe, O. (2015). Impact of workplace conflict management on organizational performance: A case of Nigerian manufacturing firm. Journal of Management and Strategy, 6 (2), 83-92. Available atwww.sciedupress.com, retrieved on $2 / 10 / 15$.

Ibekwe O. (2010) Manpower Planning and Economic Development in Nigeria:Some Issues of the Moment in Nigeria in Journal of Economic and Social Student Studies, Vol. 16, No. 1 March 2010.

Idubor, R. (2010) The Imperatives of Strike Action: The Nigerian Experience, Demis, Douala, Cameroon, The International Journal Series on Tropical Issues Vol. 11, No. 2

Ikelegbe A.O. (2009). Contending Perspectives and Issues in Social Policy Formulation and Reforms: A critical Examination of the Education Sector Reform in Nigeria, A paper presented at the workshop on National Education Reform organized by the National Forum for Policy Development, Abuja at Auditorium Hall, National Universities Commission, Abuja, on Thursday, $11^{\text {th }}$ January

Iyamu E.O.S. and Salami, L.I. (2011) Peace Studies and Conflict Resolution, General Studies Department, University of Benin, The Guide Press, Benin City.

Jones GR, Gorge JM, Hill CWL, (2010). Contemporary Management, McGraw-Hill, Boston, MA. Second Edition, ISBN: 0-13-525858-8

Odigie, S.A. (2012) State Intervention in Industrial Relations in Nigeria, Warri〉; Exco Sivo Press.

Okoh O.A. (2015), Personnel and Human Resources Management in Nigeria, Lagos: Amfitop Books.

Uhunmwuangho, S.O. and Epelle A. (2011) - Strategies for Managing Challenges and Ensuring Effective Governance in Local Governments in Nigeria, Nigerian Journal of Citizenship Education Vol.7 No.2 published by the Faculty of Education, University of Benin, (pp.120 - 129)

Website: Wikipediahttp://enwikipedia.org/wiki/Tradeunion. accessed on $12^{\text {th }}$ July, 2021 